\title{
«La paz perfecta», una mirada a la justicia transicional frente al Derecho Internacional
}

\author{
«The perfect peace» a look at transitional justice \\ against International Law
}

\author{
José Rafael QUijano JUVINAO \\ Universidad Externado de Colombia \\ jose.quijanoj@gmail.com
}

RECIBIDO: 20/04/2017 / ACEPTADO: 11/03/2018

\begin{abstract}
Resumen: La justicia transicional en los países de Latinoamérica tiene un largo recorrido, tanto en su doctrina como en su legislación; pero su aplicación ha traído consigo, en ciertos casos, la vulneración del derecho internacional, en concreto el derecho internacional de los derechos humanos $(\mathrm{DDHH})$ y el derecho internacional humanitario (DIH). El presente escrito muestra la estructura del modelo actual de justicia transicional en Colombia y lo que se pretende implementar con los acuerdos de La Habana, y propone una reflexión sobre los límites de la autonomía legislativa de los estados frente al diseño y desarrollo de sus propios modelos de justicia transicional
\end{abstract}

Palabras clave: Justicia Transicional, Paz, Colombia, Derechos Humanos, Límites, Derecho Internacional Humanitario, Derecho Internacional de los Derechos Humanos, Corte Penal Internacional.

\begin{abstract}
Transitional justice in the countries of Latin America has a long history, both in its doctrine as in its legislation, but implementation has brought the breach of international law, in concrete international law of human rights and international humanitarian law. This document shows the structure of the current model of transitional justice in Colombia and what is to be implemented with Havana agreements, and offers a reflection about limits of legislative autonomy of the states against the design and development of its own transitional justice models.
\end{abstract}

Keywords: Transitional Justice, Peace, Colombia, Human Rights, Limits, International Humanitarian Law, International Human Rights Law, International Criminal Court.

Sumario: INTRODUCCIÓN. 1. LA JUSTICIA TRANSICIONAL EN COLOMBIA. 1.1. Ley 387 del 18 de julio de 1997: «Ley de atención y asistencia a desplazados». 1.2. Ley 418 del 26 diciembre de 1997: «Ley de orden público» 1.3. Modelo Normativo de Justicia Transicional. 2. ACUERDO FINAL PARA LA TERMINACIÓN DEL CONFLICTO Y LA CONSTRUCCIÓN DE UNA PAZ ESTABLE Y DURADERA; PUNTO 5: UN NUEVO MODELO DE JUSTICIA TRANSICIONAL PARA COLOMBIA. 2.1. La Comisión para el Esclarecimiento de la Verdad, la Convivencia y la No Repetición. 2.2. La Unidad para la Búsqueda de Personas dadas por Desaparecidas en el contexto y en razón del conflicto armado. 2.3. La Jurisdicción Especial para la Paz. 2.4. Medidas de reparación integral para la construcción de la paz. 2.5. Garantías de no repetición. 3. UNAAPROXIMACIÓN DEL DERECHO INTERNACIONAL A UN MODELO PROPIO DE JUSTICIA TRANSICIONAL. CONCLUSIONES. BIBLIOGRAFÍA.

\section{INTRODUCCIÓN}

L

o primero que debo manifestar es que, muy a pesar del título que seleccioné para el presente artículo, el lector no va encontrar una receta de cómo fabricar un ambiente de paz para su contexto nacional determinado. Tampoco se plantea en el artículo que el «Acuerdo Final para la Terminación del Conflicto y la Construcción de una Paz Estable y Duradera» firmado ente 
el Gobierno colombiano y las Fuerzas Armadas Revolucionarias de Colombia (FARC-EP) constituya una «paz perfecta», dado que esta noción en sí misma no es un concepto que podamos definir debido a que carece de una idea equiparable que nos permita hacer una comparación objetiva para determinar si corresponde a la noción especificada; más aún la definición de «paz perfecta» puede variar de persona a persona, haciendo totalmente imposible llegar a tener una noción única de lo que pueda significar (Platón, el filósofo griego, ya lo manifestaba cuando en La República plantea el mito de la caverna: una cosa es la idea que percibe cada quien, otra el concepto ideal de la noción) ${ }^{1}$. En sí misma la noción de «paz perfecta» no es posible de definir, y evidentemente esta discusión no es el objeto de este artículo.

Dicho objeto es permitirle al lector un acercamiento claro a los principales puntos del «Acuerdo Final para la Terminación del Conflicto y la Construcción de una Paz Estable y Duradera», en específico en lo relacionado con la justicia transicional (punto 5 del acuerdo), contrastando lo acordado en Colombia con el derecho internacional humanitario ${ }^{2}$, el derecho internacional de los derechos humanos ${ }^{3} \mathrm{y}$ el derecho penal internacional ${ }^{4}$, desde una perspectiva académica.

1 Platón, La República, Traducción José Tomas y García, Panamericana, Bogotá, 1997, p. 267.

$2 \ll$ El derecho internacional humanitario (DIH) es un conjunto de normas que, por razones humanitarias, trata de limitar los efectos de los conflictos armados. Protege a las personas que no participan o que ya no participan en los combates y limita los medios y métodos de hacer la guerra. El DIH suele llamarse también «derecho de la guerra» $\mathrm{y}$ «derecho de los conflictos armados». El DIH es parte del derecho internacional, que regula las relaciones entre los Estados. Está integrado por acuerdos firmados entre Estados -denominados tratados o convenios-, por el derecho consuetudinario internacional que se compone a su vez de la práctica de los Estados que éstos reconocen como obligatoria, así como por principios generales del derecho. El DIH se aplica en situaciones de conflicto armado. No determina si un Estado tiene o no tiene derecho a recurrir a la fuerza. Esta cuestión está regulada por una importante parte -pero distinta- del $\mathrm{DIH}$, que figura en la Carta de las Naciones Unidas» Comité Internacional de la Cruz Roja (CIRC), Servicio de Asesoramiento en Derecho Internacional Humanitario «¿Qué es el derecho internacional humanitario?», https:/www.icrc.org/spa/assets/files/other/dih.es.pdf, 2004 [10-09-2016].

$3 \ll$ El derecho internacional de los derechos humanos es un conjunto de normas internacionales que reafirman los derechos y la dignidad de todos los seres humanos -mujeres, hombres y niños- sin discriminación.» ONU Mujeres, «Derecho Internacional de los Derechos Humanos», http://www.endvawnow.org/es/articles/1485-derecho-internacional-de-los-derechos-humanos. html, 2009 [12-09-2016].

$4 \ll$ El derecho penal internacional es la rama del derecho por la cual se prohíben ciertas categorías de conducta consideradas delitos graves; se regulan procedimientos para la investigación, el enjuiciamiento y el castigo por esas categorías de conducta, y se considera que una persona que perpetre uno de esos delitos será responsable personalmente. Para hacer respetar el derecho 
Esta mirada permitirá a cada lector hacer un juicio y determinar con los elementos suministrados qué se pretende hacer en Colombia en materia de justicia transicional de cara a los acuerdos firmados entre el Estado y un grupo armado subversivo.

La justicia transicional en una etapa temprana «fue utilizada por el vencedor con dos propósitos: por un lado, castigar los crímenes del vencido y, por otro, asegurar la impunidad de sus propios crímenes. En su segunda etapa, en la que el fin del conflicto es producto de una negociación entre actores armados, la justica transicional fue un instrumento de impunidad, de perdones mutuos, sin verdad (o al menos no una verdad completa) y sin reparación a las víctimas. En su tercera etapa, el derecho internacional de los derechos humanos y el Estatuto de Roma han hecho que la justicia transicional se acerque cada vez más a la idea del derecho como un límite al poder. Se trata de una nueva visión de la justicia transicional ya no como un derecho local contingente excepcional sino como un derecho universal estatuido, basado en el principio de legalidad y parte integral del Estado social de derecho» ${ }^{5}$.

\section{LA JUSTICIA TRANSICIONAL EN COLOMBIA}

Colombia es un país que ha vivido durante los últimos 52 años en continuo conflicto armado, el que ha variado su intensidad con el tiempo y con el pasar de los años en algunos momentos se ha llegado a disipar. Durante estas décadas de conflicto se han expedido varias normas para el reconocimiento de los derechos de las víctimas y el tratamiento de los diferentes actores armados;

internacional humanitario, es fundamental reprimir las violaciones graves de esta rama del derecho, especialmente si se tiene en cuenta la gravedad de algunas violaciones, consideradas crímenes de guerra, cuyo castigo redunda en interés de la comunidad internacional en su conjunto. Dado que los crímenes internacionales incluyen cada vez más elementos extraterritoriales, los cuales exigen una mayor interacción entre Estados, es más urgente coordinar el respeto de esos principios. Los Estados deben acatar tanto los principios internacionales como los principios nacionales previstos en el respectivo derecho penal interno y los principios específicos contenidos en los instrumentos regionales en los que son Parte.» Comité Internacional de la Cruz Roja (CIRC), Servicio De Asesoramiento en Derecho Internacional Humanitario, «Principios Generales del Derecho Penal Internacional», https://www.icrc.org/spa/assets/files/2014/generalprinciples-of-criminal-icrc-spa.pdf, 2014 [10-10-2016].

5 IBARRA, A., «Justicia transicional: la relación Derecho-Poder en los momentos de transición», Revista de Derecho, 45 (enero-junio de 2016), http://rcientificas.uninorte.edu.co/index.php/derecho/article/viewArticle/7176/8248\#num7, 2016 [28-10-2016]. 
esto es lo que podemos denominar un modelo de justicia transicional, sobre el cual haremos un breve recuento.

Para algunos autores la justicia transicional en Colombia nace con la Ley 975 de 2005, mejor conocida como «Ley de Justicia y Paz», y su discusión legislativa; pero si definimos la justicia transicional como «el conjunto de teorías y prácticas derivadas de los procesos políticos por medio de los cuales las sociedades tratan de ajustar cuentas con un pasado de atrocidad e impunidad, y hacen justicia a las víctimas de dictaduras, guerras civiles y otras crisis de amplio espectro o larga duración, con el propósito de avanzar o retornar a la normalidad democrática ${ }^{6}$, se debe afirmar que en el caso colombiano existen elementos normativos anteriores a esta ley que se encuentran bajo el espectro de esta definición y hacen parte del modelo de justica transicional inclusive al día de hoy.

La justicia transicional debe estar compuesta por políticas interrelacionadas práctica y conceptualmente, entre las cuales destacan: acciones penales para los mayores responsables, reparaciones a las víctimas, reformas de instituciones públicas implicadas en los abusos y comisiones de la verdad u otras formas de investigación. ${ }^{7}$

\subsection{Ley 387 del 18 de julio de 1997: «Ley de atención y asistencia a desplazados»}

Esta ley estableció el marco jurídico aplicable a la población víctima del desplazamiento forzado como consecuencia de la violencia, denominación que se le dio por años al conflicto armado interno en Colombia. Creó herramientas para prevenir el desplazamiento forzado, brindar ayuda humanitaria, facilitar el retorno, la estabilización socioeconómica y la asistencia de este grupo vulnerable.

Si bien la definición de conflicto armado interno fue adoptada en la legislación colombiana cuando se ratificó el Protocolo II adicional a los acuerdos de Ginebra en 1994 con la Ley 171, por primera vez con la Ley 387 el Estado reconoció en un instrumento normativo la crisis humanitaria que significaba

6 VAlenCia, H., «Introducción a la justicia transicional», Conferencia magistral impartida en la Cátedra Latinoamericana «Julio Cortázar» de la Universidad de Guadalajara, 2007, p. 1.

7 The International Center for Transitional Justice, «¿Qué es la Justicia Transicional?», https:// www.ictj.org/es/que-es-la-justicia-transicional [13-10-2016]. 
el conflicto armado interno y estableció un proceso para la atención a las víctimas de desplazamiento como consecuencia de este conflicto.

Ahora, al margen de la discusión sobre la transformación de la noción de víctima en el ordenamiento interno colombiano, donde pasamos de la denominada parte civil dentro del proceso penal a un sujeto procesal con reconocimiento a los derechos a la verdad, justicia, reparación y garantías de no repetición dentro del $\mathrm{mismo}^{8}$, las nociones de víctima para procesos no judiciales como aquellos relacionados con la reparación y atención han sido introducidas a nuestra legislación con la dinámica de construcción de paz por parte del Estado colombiano. Adicionalmente ha traído como consecuencia la distinción entre hecho punible o delito y el hecho victimizante usado en las instituciones no judiciales para referirse a las víctimas del conflicto.

\subsection{Ley 418 del 26 diciembre de 1997: «Ley de orden público»}

Este marco normativo contiene diversos mecanismos tendientes a conseguir la convivencia pacífica, la reconciliación y facilitar la desmovilización de los grupos armados al margen de la ley. Actualmente está vigente como consecuencia de prórrogas, modificaciones y adiciones contenidas en las leyes 548 del 23 de diciembre de 1999, 782 del 23 de diciembre de 2002, 1106 del 22 de diciembre de 2006, 1421 del 21 de diciembre de 2010 y 1738 del 18 de diciembre de 2014.

La fórmula contenida en la ley 418 de 1998 es la escogencia concreta de la solución pacífica del conflicto en Colombia, lo que estaba inmerso en una posición política que no podía desconocerse por parte del Gobierno. La Corte Constitucional en su momento reconoció que existía una amplia libertad de configuración política que le otorgaba al legislador la escogencia de los mecanismos tendientes a la solución del conflicto armado en Colombia9.

8 Entre otras sentencias que constituyeron un hito para la transformación de la noción de víctima se encuentran: Corte constitucional colombiana, C-293 de 1995, C. Gaviria. C-163 de 2000, F. Moron, C-1149 de 2001 J. Araujo. T-1267 de 2001. R. Uprimny, C-228 de 2002. M. Cepeda y E. Montealegre, C-014 de 2004 J. Córdoba, y C-454 de 2006. http://www.corteconstitucional. gov.co/relatoria/ [10-09-2016]. Dichas sentencias permitieron la superación de la noción de los derechos de las víctimas basados en una pretensión puramente patrimonial hacia el derecho a la participación activa en todo el proceso con la finalidad de salvaguardar el derecho a la justicia, verdad, reparación y garantías de no repetición.

9 Moron, F., «Corte constitucional colombiana. C-048 de 2001», http://www.corteconstitucional.gov.co/relatoria/2001/C-048-01.htm, 2001 [15-10-2016]. 
Esta ley no solo describe un proceso de atención a víctimas de hechos violentos relacionados con el conflicto armado; también regula el proceso de desmovilización individual y colectiva de miembros de grupos armados al margen de la ley, regulación empleada aún hoy para las desmovilizaciones. Adicionalmente establece diferentes beneficios jurídicos para los delitos políticos y conexos que afectaban la responsabilidad penal y la acción penal y crea un régimen de excepciones para cuando el desmovilizado hubiese cometido delitos graves, casos en los que no es viable la aplicación de dichos beneficios.

Así mismo cuando el proceso penal está en tránsito el desmovilizado puede solicitar según proceda, y en concordancia con el estado del respectivo proceso penal, la cesación de procedimiento, la resolución de preclusión de la investigación y la resolución inhibitoria, siempre y cuando no haya sido aún condenado mediante sentencia ejecutoriada; para esta última situación existe el régimen de indultos previsto en la misma ley. ${ }^{10}$

\subsection{Modelo Normativo de fusticia Transicional}

\section{i. Ley 975 del 25 de julio de 2005: Ley de Justicia y Paz}

En esta norma se establece un marco jurídico preciso para promover la desmovilización mediante el establecimiento de un procedimiento penal especial, respetando los derechos de las víctimas a la verdad, justicia, reparación y garantías de no repetición. Con esta ley por primera vez se incluyó en el discurso legislativo el término de justicia transicional, si bien esta disposición conocida como la Ley de Justicia y Paz fue concebida como una norma de alternatividad penal más que como un instrumento de justicia transicional.

Como ya se manifestó, en Colombia hubo un proceso de trasformación de la noción de víctima, lo que implicó una ampliación de este concepto y de los derechos que se les reconocían a las víctimas tanto del conflicto como de los delitos fuera de este. Los derechos de las víctimas se introdujeron a partir del Código de Procedimiento Penal del año $2000^{11}$, aunque debe aclararse que no estaban expresamente contempladas en esta normativa. Fue a través de la

10 Congreso de Colombia, Ley 418 de 1998. Ley de Orden Público, http://www.secretariasenado. gov.co/senado/basedoc/ley_0418_1997.html, 1998 [10-10-2016].

11 Congreso de Colombia. Ley 600 de 2000. Código de procedimiento penal, http://www.secretariasenado.gov.co/senado/basedoc/ley_0600_2000.html, 2000 [11-10-2016]. 
jurisprudencia que se reconocieron los derechos a las víctimas, y solo con la expedición de la Ley 975 de 2005 se trajeron al panorama legislativo las nociones de derechos a las víctimas a la verdad, a la justicia, a la reparación y las garantías de no repetición.

El proceso penal especial que instaura la Ley 975 se reserva para aquellos desmovilizados que cometieron los delitos más graves, delitos que por su naturaleza los excluían del tratamiento normativo previsto en la Ley 418 de 1998. Los desmovilizados que se sometían a este tratamiento penal de manera voluntaria eran postulados por el Gobierno nacional, y la Fiscalía General de la Nación iniciaba el proceso penal basado en un principio fundamental, el cual era la confesión a través de audiencias de versión libre, donde el desmovilizado en cualquier momento podría renunciar al proceso y pasar a ser investigado por la justicia ordinaria ${ }^{12}$.

Finalizada la etapa de versión libre la Fiscalía procedía a las audiencias de imputación y formulación de cargos, donde el desmovilizado podía aceptar o no responsabilidad en los delitos de los cuales se le acusaba. En caso de no aceptarla se remiten a la jurisdicción ordinaria; si el postulado aceptaba su responsabilidad se procedía con la imposición de una sanción sustituida por una pena alternativa entre 5 y 8 años de privación efectiva de la libertad y 4 años más de seguimiento. Adicionalmente se establecía un incidente de reparación que hacía parte integral de la sentencia, donde se determinaba quiénes son las víctimas y la forma de repararlas ${ }^{13}$.

\section{ii. Ley 1424 del 29 de diciembre de 2010: Ley de desmovilizados}

Esta ley abrió el camino para que aproximadamente diecisiete mil desmovilizados de grupos armados organizados al margen de la ley, particularmente de grupos paramilitares, se vincularan a la reintegración. Esta ley estableció un mecanismo no judicial de contribución a la verdad con beneficios dentro del desarrollo de las investigaciones y procesos penales; adicionalmente dispuso de manera expresa los actos de reintegración que deben efectuar los desmovilizados para ser beneficiarios de estas concesiones jurídicas. La norma

\footnotetext{
12 Congreso de Colombia. Ley 975 de 2005. Ley de Justicia y Paz, http://www.secretariasenado. gov.co/senado/basedoc/ley_0975_2005.html, 2005 [13-10-2016].

13 Ibidem.
} 
se promulgó para otorgar beneficios jurídicos a aquellos desmovilizados que no eran considerados delincuentes políticos y que se encontraban fuera del tratamiento establecido en la Ley 418 de 1998.

iii. Ley 1448 del 10 de junio de 2011: Ley de víctimas y restitución de tierras

Esta norma buscó garantizar la adopción de medidas de asistencia, atención y reparación integral para las víctimas. Con la expedición de esta ley se acopló la legislación nacional a los estándares internacionales que rigen la materia, con adaptaciones que responden a las particularidades del caso colombiano, para lograr la reparación integral a las víctimas.

Esta ley se creó con dos finalidades específicas: la reparación integral a las víctimas, así como diseñar y construir un proceso para la restitución de tierras despojadas como consecuencia del conflicto armado. La reparación integral a las víctimas no se concibió sólo como una indemnización, económicamente hablando; implica medidas dirigidas a la restitución, indemnización, rehabilitación, satisfacción y garantías de no repetición, además del compromiso de acompañamiento por parte del Estado en diferentes aspectos de una reparación integral, como la educación, la salud, la vivienda, programas de empleo y de generación de ingresos, entre otras medidas no solo de carácter individual sino también de carácter colectivo.

iv. Ley 1592 del 3 de diciembre de 2012: Reforma a la Ley de Justicia y Paz

Con la finalidad de ajustar la ley 975 de 2005 a los estándares internacionales y dar celeridad, eficiencia y eficacia al proceso penal especial consagrado en esta, el Gobierno Nacional expidió la ley 1592 de 2012, la cual simplificó el proceso de audiencias, transformó los mecanismos de reparación adecuándolos a la ley 1448 de 2011 y otorgó la posibilidad de priorizar los casos a investigar.

v. Acto Legislativo 01 de julio 31 de 2012: Marco Jurídico para la Paz

En el Acto Legislativo 01 se establecen instrumentos jurídicos de justicia transicional en el marco del artículo 22 de la Constitución Política, el cual consagra que la paz es un derecho y un deber de obligatorio cumplimiento. Esta 
disposición pretendió reenfocar la estrategia del Estado colombiano para la concepción y desarrollo de mecanismos de justicia transicional, mediante el diseño y aplicación de criterios de selección positiva y priorización, los cuales debían ser establecidos por el legislador de forma que la estrategia de persecución penal se enfocara en «los máximos responsables» de la comisión de graves crímenes.

El marco jurídico para la paz impulsa la creación de mecanismos de carácter extrajudicial para el esclarecimiento de la verdad y la reparación a las víctimas, criterios de selección y priorización para el juzgamiento de los máximos responsables y los más graves crímenes, entre otros.

\section{ACUERDO FINAL PARA LA TERMINACIÓN DEL CONFLICTO Y LA CONSTRUCCIÓN DE UNA PAZ ESTABLE Y DURADERA; PUNTO 5: UN NUEVO MODELO DE JUSTICIA TRANSICIONAL PARA COLOMBIA}

El denominado punto 5 del Acuerdo creaba el Sistema Integral de Verdad, Justicia, Reparación y No repetición. Este punto se acordó el 15 de diciembre de 2015, entre el Gobierno de Colombia y el grupo armado al margen de la ley conocido como las FARC-EP. La idea de este acuerdo es la construcción de un sistema institucional que permita a la nación colombiana una transición de la situación de conflicto armado interno a la consolidación de la democracia, con la mayor satisfacción posible de los derechos de las víctimas. ${ }^{14}$

La creación de un sistema institucional e integral de verdad, justicia, reparación y no repetición permite una reconstrucción de la verdad histórica de lo acontecido y garantiza la seguridad jurídica de quienes participen en él, dado que fija las reglas de los procesos y procedimientos judiciales y extrajudiciales, y se espera que contribuya a garantizar la convivencia, la reconciliación y la no repetición del conflicto armado interno. ${ }^{15}$

Este nuevo modelo de justicia transicional es un sistema compuesto por mecanismos y medidas de orden judiciales como extrajudiciales, que deberán iniciar su funcionamiento de manera conjunta y coordinada. El esquema institucional de este sistema está compuesto por los siguientes mecanismos y medidas.

\footnotetext{
14 Gobierno de la República de Colombia y FARC-EP, «Acuerdo Final para la Terminación del Conflicto y la Construcción de una Paz Estable y Duradera», http://www.acuerdodepaz.gov.co/ el-acuerdo-de-paz, 2016 [12-09-2016], p. 112 ss.

15 Ibidem.
} 


\subsection{La Comisión para el Esclarecimiento de la Verdad, la Convivencia y la No Repetición}

La comisión creada por el acuerdo es de carácter imparcial, independiente, transitorio y extrajudicial, con enfoque territorial; lo que busca es la satisfacción del derecho a la verdad de las víctimas en su dimensión individual $\mathrm{y}$ de la sociedad en general en su dimensión colectiva ${ }^{16}$.

Por otra parte, los objetivos de esta Comisión están planteados en los siguientes términos: (1) la Comisión deberá contribuir al esclarecimiento de lo ocurrido y ofrecer una explicación amplia de la complejidad del conflicto; (2) deberá promover y contribuir al reconocimiento. Eso significa el reconocimiento de las víctimas como ciudadanos a quienes les fueron vulnerados sus derechos, y en general el reconocimiento por parte de toda la sociedad de ese legado de violaciones e infracciones como algo que merece el rechazo de todos y que no se debe ni se puede repetir; (3) la Comisión promoverá la convivencia en los territorios ${ }^{17}$.

El mandato de esta comisión es esclarecer y promover el reconocimiento de: (1) prácticas y hechos que constituyen graves violaciones a los derechos humanos y graves infracciones al derecho internacional humanitario (DIH); (2) las responsabilidades colectivas del Estado, incluyendo el Gobierno y los demás poderes públicos, de las FARC-EP, de los paramilitares, así como de cualquier otro grupo, organización o institución, nacional o internacional, que haya tenido alguna participación en el conflicto; (3) el impacto humano y social del conflicto en la sociedad; (4) el impacto del conflicto sobre el ejercicio de la política y el funcionamiento de la democracia en su conjunto, incluyendo el impacto sobre los partidos y movimientos políticos y sociales, en particular los de la oposición, entre otros ${ }^{18}$.

Las comisiones de la verdad son mecanismos frecuentemente creados en procesos de transición con la finalidad de esclarecer patrones de violencia, en este caso se creó no como un mecanismo para administrar justicia sino para contribuir a la verdad, promover y contribuir al reconocimiento de

16 Ibidem.

17 Gobierno de la República de Colombia y FARC-EP, «Comunicado Conjunto\#53 Informe Conjunto De La Mesa De Conversaciones», http://centromemoria.gov.co/wp-content/uploads/2015/06/ Acuerdo-para-establecer-la-comisi\%C3\%B3n-de-esclarecimiento-de-la-verdad.pdf, 2016 [1009-2016], p 2 ss

18 Ibidem. 
las víctimas y de la responsabilidad de quienes participaron en el conflicto armado y promover la convivencia en los territorios, mediante un ambiente de diálogo ${ }^{19}$.

Se espera como resultado de esta comisión un informe final, la creación de espacios en los ámbitos nacional, regional y territorial, y que promueva la participación de los diferentes sectores de la sociedad, incluyendo de quienes hayan participado directamente en el conflicto.

\subsection{La Unidad para la Búsqueda de Personas dadas por Desaparecidas en el contexto y en razón del conflicto armado}

Este mecanismo de carácter humanitario y extrajudicial busca establecer lo sucedido con las personas desaparecidas con ocasión del conflicto armado interno, y de esa manera contribuir a satisfacer los derechos de las víctimas a la verdad y la reparación integral ${ }^{20}$.

Dentro de los objetivos de esta unidad se encuentra buscar a aquellas personas que murieron en poder de las organizaciones armadas ilegales, que hayan sido víctimas de desaparición forzada o que se puedan haber visto apartados forzosamente de sus familias, siempre en razón o con ocasión del conflicto armado; en general esta unidad tendrá como función la búsqueda de todos quienes hayan participado en las hostilidades desprendidas del conflicto armado interno ${ }^{21}$.

\subsection{La furisdicción Especial para la Paz}

Esta jurisdicción especial es el componente de justicia del denominado Sistema Integral dentro de los acuerdos de paz entre el Estado colombiano y las FARC-EP. Se trata de un mecanismo de carácter judicial que busca, ante todo, la satisfacción de los derechos de las víctimas, en particular el derecho a la justicia; además a través de esta jurisdicción especial para la paz

19 Gobierno de la República de Colombia y FARC-EP, «Acuerdo Final para la Terminación del Conflicto y la Construcción de una Paz Estable y Duradera», http://www.acuerdodepaz.gov.co/ el-acuerdo-de-paz, 2016 [12-09-2016], p. 112 ss.

20 Ibidem.

21 Ibidem. 
se busca hacer una contribución efectiva para garantizar sus derechos a la verdad, la reparación y la no repetición, y contribuir a la consolidación de la $\mathrm{paz}^{22}$.

En todos los procesos exitosos (así como en los fallidos) que el Gobierno de Colombia ha desarrollado con diversos grupos armados al margen de la ley, es la primera vez que un gobierno y un grupo armado ilegal crean dentro de un acuerdo de paz un sistema jurisdiccional encargado de investigar, juzgar y sancionar las conductas cometidas durante la ocurrencia del conflicto armado interno y estrechamente ligadas a lo acontecido en su desarrollo, en particular los delitos más graves y aquellos de mayor connotación ${ }^{23}$.

Esta jurisdicción especial está compuesta de la siguiente manera: una Sala de Reconocimiento de verdad, de responsabilidad y de determinación de los hechos y conductas, el Tribunal para la Paz, la Sala de Amnistía o indulto, la Sala de definición de situaciones jurídicas y una Unidad de Investigación y acusación ${ }^{24}$.

La jurisdicción se aplicará a todos quienes habiendo participado de manera directa $o$ indirecta en el conflicto armado cometieron delitos en el contexto y en razón de éste. En concreto la jurisdicción podrá investigar a los miembros de grupos guerrilleros que suscriban un acuerdo final de paz con el Gobierno, una vez hayan dejado las armas; a los agentes del Estado que hayan cometido delitos en razón y con ocasión del conflicto armado y a aquellas personas que sin formar parte de las organizaciones o grupos armados hayan participado como financiadores o colaboradores ${ }^{25}$.

- Sala de amnistías e indultos.

Con la terminación de las hostilidades, y en concordancia con el derecho internacional humanitario y la Constitución colombiana, se otorgarán amnistías o indultos por delitos políticos y aquellos delitos conexos, para la cual la jurisdicción especial para la paz contará con un Sala de Amnistía o indulto, que será la encargada de tramitar indultos o amnistías cuando haya lugar a ello. El acuerdo es claro cuando manifiesta que «No serán objeto de amnistía ni indulto ni de beneficios equivalentes los delitos de lesa humanidad, el genocidio, los graves crímenes de guerra, la toma de

22 Ibidem.

23 Ibidem.

24 Ibidem.

25 Ibidem. 
rehenes u otra privación grave de la libertad, la tortura, las ejecuciones extrajudiciales, la desaparición forzada, el acceso carnal violento y otras formas de violencia sexual, la sustracción de menores, el desplazamiento forzado, además del reclutamiento de menores conforme a lo establecido en el Estatuto de Roma» ${ }^{26}$.

- Tribunal para la Paz.

Para aquellos delitos que por su naturaleza no sean objeto de amnistía o indulto, la Jurisdicción especial para la paz se encargará de juzgarlos y sancionarlos. En este sentido el Tribunal para la Paz impondría tres tipos de sanciones: las denominadas sanciones propias, las alternativas y las ordinarias. Las sanciones propias se impondrán a quienes reconozcan verdad y responsabilidad ante la jurisdicción; estas sanciones tendrán contenido restaurativo y reparador, así como un componente de restricción efectiva de libertades y derechos, tales como la libertad de residencia y movimiento, y tendrán una duración de entre 5 y 8 años ${ }^{27}$.

Las penas alternativas se impondrán a quienes reconozcan tardíamente verdad y responsabilidad, siempre y cuando lo hagan antes de proferir sentencia, y tendrán una finalidad netamente retributiva de 5 a 8 años de privación efectiva de la libertad; y las sanciones ordinarias serán para aquellas personas que no reconozcan responsabilidad y vencidas en juicio sean condenadas por parte del Tribunal. En todo caso la privación efectiva de la libertad no será inferior a 15 años ni superior a 20 en el caso de conductas muy graves ${ }^{28}$.

- Sala de Definición de Situación Jurídica.

La Sala de Definición de Situación Jurídica tendrá como función principal, tal cual lo indica su nombre, definir la situación jurídica de todos quienes hayan accedido al componente de justicia de sistema integral en dos supuestos principalmente: el primero, que por la naturaleza de sus conductas estas no sean susceptibles de indulto o amnistía, y el segundo, que estas personas ya hayan sido condenadas por los delitos que son competencia de la jurisdicción especial ${ }^{29}$.

26 Ibidem.

27 Ibidem.

28 Ibidem.

29 Ibidem. 
- La Unidad de Investigación y Acusación

Esta unidad se encargaría de la investigación y acusación para las personas que se sometan a la jurisdicción especial cuando no haya reconocimiento colectivo o individual de responsabilidad, para que el sistema condene o absuelva en concordancia con dicha investigación ${ }^{30}$.

En todo caso, siendo esta jurisdicción especial para la paz una medida especial y transitoria, para que se pueda acceder a y/o mantener cualquier tratamiento especial de los contenidos en los acuerdos será necesario contribuir de manera efectiva a la verdad, la reparación y la no repetición en los distintos mecanismos; de no ser así la consecuencia lógica es que entre a operar la jurisdicción ordinaria ${ }^{31}$.

\subsection{Medidas de reparación integral para la construcción de la paz}

Dentro del «Acuerdo Final para la Terminación del Conflicto y la Construcción de una Paz Estable y Duradera» se contemplan medidas dirigidas a la reparación integral de las víctimas, en específico 8 medias dirigidas a este fin: (1) actos tempranos de reconocimiento de responsabilidad colectiva; (2) acciones concretas de contribución a la reparación por parte de quienes han causado daños; (3) fortalecimiento de los procesos de reparación colectiva y articulación con los programas de desarrollo; (4) ampliación y fortalecimiento de las estrategias de rehabilitación psicosocial a nivel individual y comunitario; (5) realización de procesos colectivos de retorno de personas en situación de desplazamiento y fortalecimiento de la reparación de víctimas en el exterior; (6) fortalecimiento de los procesos de restitución de tierras; (7) adecuación y fortalecimiento participativo de la política de atención y reparación integral a víctimas y (8) compromiso de las FARC-EP de contribuir a la reparación integral, incluyendo reparación material. Estas medidas buscan lograr en conjunto con el modelo existente en Colombia (Ley 1448 de 2011) la reparación real y efectiva de las víctimas del conflicto armado interno ${ }^{32}$.

30 Ibidem.

31 Ibidem.

32 Ibidem. 


\subsection{Garantías de no repetición}

En sí mismo el «Acuerdo Final para la Terminación del Conflicto y la Construcción de una Paz Estable y Duradera» es un catálogo de garantías de no repetición de las causas que dieron origen al conflicto o que se desarrollaron durante el mismo; la puesta en marcha de varios de los puntos del acuerdo, comenzando por los procesos y procedimientos del Sistema Integral de Verdad, Justicia, Reparación y No Repetición constituye una garantía de no repetición. Otro punto fundamental para tener en cuenta es el punto 3, que busca garantizar la terminación definitiva del conflicto armado, el cese de hostilidades bilateral y definitivo y la dejación de las armas por parte de las FARC-EP; temas como la reforma rural integral, la participación en política y la solución al problema de las drogas ilícitas son medidas que contribuirán a cambiar las condiciones que han facilitado la persistencia de la violencia en el territorio colombiano ${ }^{33}$.

Este nuevo modelo de justicia transicional desarrollado en los acuerdos de La Habana se diseñó para que pudieran participar todos los actores del conflicto armado y sus respetivas víctimas; con el fin de cumplir los objetivos del nuevo modelo los diferentes mecanismos tienen como premisa incentivar la colaboración de quienes tuvieron una participación directa o indirecta en el conflicto armado y cometieron delitos en el desarrollo de éste, permitiendo la investigación, judicialización y sanción de las conductas cometidas y sobre todo el respeto y garantía de los derechos de las víctimas a la verdad, justicia, reparación y garantías de no repetición.

\section{UNA APROXIMACIÓN DEL DERECHO INTERNACIONAL A UN MODELO PROPIO DE JUSTICIA TRANSICIONAL}

La construcción e implantación de un modelo propio de justicia transicional para un país que ha culminado un ciclo de violencia generalizado, o está haciendo tránsito a la consolidación de la democracia, se debe construir con medidas ajustadas a las realidades que dieron origen a esas situaciones en cada país ${ }^{34}$;

33 Ibidem.

34 «In view of the increasing trend to utilize the measures of truth-seeking, justice initiatives, reparation and guarantees of non-recurrence without heeding the characteristics of the contexts in which they are applied, the Special Rapporteur underlines that it is crucial to clearly identify and assess the preconditions in any given country and address them in a manner fine-tuned, targeted 
no se puede buscar una salida política a estos contextos de graves violaciones de derechos humanos sobre un esquema rígido que desconozca las condiciones del país especifico donde se pretende desarrollar o poner en marcha. Por lo tanto, al diseñar medidas de reparación adecuadas para una situación determinada es preciso tener en cuenta factores relativos al contexto, como el nivel general de realización de los derechos económicos, sociales y culturales y los recursos disponibles $^{35}$.

Las medidas, mecanismos, procesos y procedimientos jurídicos y/o políticos que un país implemente en su modelo de justicia transicional no se encuentran en un listado númerus clausus, por el contrario cada país tiene la libertad de seleccionar los mecanismos que estime necesarios para conseguir el tránsito a la consolidación de la paz. «No estamos ante una lista cerrada. Cada país va incorporando nuevas medidas. La memorialización, por ejemplo, que se compone de diversas iniciativas destinadas a mantener viva la memoria de las víctimas mediante la creación de museos y monumentos, y otras medidas simbólicas como el cambio de nombre de los espacios públicos, se ha convertido en parte importante de la justicia transicional en la mayoría de los países del mundo» ${ }^{36}$. Es bueno que las partes en un conflicto armado negocien y conozcan todos los estándares internacionales y el abanico de modalidades de combinación entre mecanismos, para que puedan ser creativos y maximizar los márgenes de maniobra, siempre respetando las normas internacionales ${ }^{37}$.

Pero la pregunta que surge en este punto es ¿existe un límite a la discrecionalidad de un país para diseñar e implementar su propio modelo de justicia transicional? Y la respuesta debe ser clara: sí existe un límite. La autonomía de los estados en el momento de construir un modelo de justicia transicional está limitada por el derecho internacional, en especial por el Derecho Internacional

and sensitive to context.». DE GREIFF, P., Report of the Special Rapporteur on the promotion of truth, justice, reparation and guarantees of non-recurrence, United Nations, 2012, p. 6. «Los derechos de las víctimas tienen una íntima relación entre sí, en la cual no se puede entender la existencia material de uno de estos derechos sin la garantía del otro, es decir, no podemos hablar de justicia sin que se garantice la verdad o viceversa». GonZÁlEZ-SALZBERG, D., «El Derecho a la Verdad en Situaciones de Post-Conflicto Bélico de Carácter No-Internacional», Revista Colombiana de derecho internacional ildi, $\mathrm{n}^{\circ} 12$, edición especial (2008), pp. 435-468.

35 Organización Naciones Unidas (ONU), Fusticia Transicional y Derechos Económicos, Sociales y Culturales, Naciones Unidas, 2014, p. 62 y ss.

36 The International Center for Transitional Justice, «¿Qué es la Justicia Transicional?», https:// www.ictj.org/es/que-es-la-justicia-transicional [13-10-2016].

37 GómEZ-SuÁREZ, A., «Confíen en crear su propio modelo», http://www.elespectador.com/noticias/nacional/confien-crear-su-propio-modelo-articulo-550716, 2015 [12-09-2016]. 
Humanitario, el Derecho Internacional de los Derechos Humanos y el Derecho Penal Internacional, y en el espectro más amplio el límite estaría dado en las normas de derecho internacional consuetudinario entendidas como el proceso de creación normativa derivada del comportamiento de los Estados en sus relaciones, constituyéndose una práctica general aceptada como derecho ${ }^{38}$, y/o las normas ius cogens; se «ha sostenido la aplicabilidad de las normas de ius cogens que son obligatorias per se en la medida que la comunidad internacional se ha mostrado interesada en que sean perseguidos y sancionados penalmente comportamientos que atentan contra los valores comunes de la humanidad ${ }^{39}$.

Es así como el modelo de justicia transicional de un país determinado se ve limitado por los convenios internacionales suscritos por este, y aún en el hipotético caso en el que el Estado no haya suscrito ningún convenio el modelo de justicia transicional de dicho país estaría limitado por el ius cogens. Estos límites se deben configurar de juicios ex ante y ex post, esto implica que tenemos condiciones de necesario cumplimiento al momento de diseñar un mecanismo de justicia transicional y que el Estado y las personas que se sometan a estos mecanismos podrán ser juzgados internacionalmente y ser declarados responsables por el incumplimiento de las mismas.

La existencia de estos límites permite crear un nivel de legitimación más allá de las fronteras nacionales; además, la existencia de un sistema internacional de derechos humanos permite, por una parte, contribuir a evitar el deterioro de sociedades democráticas por más complejos que sean sus conflictos, permitiendo la intervención de la jurisdicción internacional, y por otra parte la existencia de normas y procedimientos jurídicos reduce la posibilidad de aplicar las normas de derechos humanos con criterios exclusivamente políticos ${ }^{40}$.

El juicio ex ante limita la discrecionalidad normativa de un estado en la obligación de respeto de las normas convencionales o consuetudinarias en el momento del diseño de su modelo propio de justicia transicional. En un estado como el colombiano estos límites están dados por la Constitución, dada la integración

38 Comité Internacional de la Cruz Roja (CIRC), International Review of de Red Cross, vol. 87, $\mathrm{n}^{\mathrm{o}} 857$ (marzo de 2005), https://www.icrc.org/spa/assets/files/other/icrc_003_0860.pdf [28-102016].

39 PigraU, A., La jurisdicción universal y su aplicación en España, RxDH, Barcelona, 2009, pp. 130131. También en apoyo de las tesis favorables a la persecución: CAPELLÀ RoIG, M., «Los crímenes contra la humanidad en el caso Scilingo», REEI, $n^{\circ} 10$ (2005).

40 Grossman, C., «Reflexiones sobre el Sistema Interamericano de Protección y Promoción de los Derechos Humanos», en La Corte y el Sistema Interamericano de Derechos Humanos, San José, 1997, p. 246. 
de la doctrina del bloque de constitucionalidad ${ }^{41}$ de acuerdo con los artículos $9^{42}$, $93^{43}, 94^{44}$ y $214^{45}$, la doctrina y la jurisprudencia de la Corte Constitucional ${ }^{46}$. El

41 Hace referencia a la inclusión de normas y principios que, sin ser parte del articulado de la Constitución política colombiana, pueden ser utilizados como parámetros del control de constitucionalidad e interpretación de las leyes, por cuanto han sido normativamente integrados a la Constitución. En relación con el tema se pueden consultar entre otras sentencias: Cconst. C-225 de 1995 Martínez, A, C-578 de 1995 Cifuentes, E, C-358 de 1997 Cifuentes, E, y C-191 de 1998 Cifuentes, E.

42 Artículo 9. Las relaciones exteriores del Estado se fundamentan en la soberanía nacional, en el respeto a la autodeterminación de los pueblos y en el reconocimiento de los principios del derecho internacional aceptados por Colombia.

43 Artículo 93. Los tratados y convenios internacionales ratificados por el Congreso, que reconocen los derechos humanos y que prohíben su limitación en los estados de excepción, prevalecen en el orden interno. Los derechos y deberes consagrados en esta Carta, se interpretarán de conformidad con los tratados internacionales sobre derechos humanos ratificados por Colombia. El Estado Colombiano puede reconocer la jurisdicción de la Corte Penal Internacional en los términos previstos en el Estatuto de Roma adoptado el 17 de julio de 1998 por la Conferencia de Plenipotenciarios de las Naciones Unidas y, consecuentemente, ratificar este tratado de conformidad con el procedimiento establecido en esta Constitución. La admisión de un tratamiento diferente en materias sustanciales por parte del Estatuto de Roma con respecto a las garantías contenidas en la Constitución tendrá efectos exclusivamente dentro del ámbito de la materia regulada en él.

44 Artículo 94. La enunciación de los derechos y garantías contenidos en la Constitución y en los convenios internacionales vigentes, no debe entenderse como negación de otros que, siendo inherentes a la persona humana, no figuren expresamente en ellos.

45 Artículo 214. Los Estados de Excepción a que se refieren los artículos anteriores se someterán a las siguientes disposiciones: 1 . Los decretos legislativos llevarán la firma del Presidente de la República y todos sus ministros y solamente podrán referirse a materias que tengan relación directa y específica con la situación que hubiere determinado la declaratoria del Estado de Excepción. 2. No podrán suspenderse los derechos humanos ni las libertades fundamentales. En todo caso se respetarán las reglas del derecho internacional humanitario. Una ley estatutaria regulará las facultades del Gobierno durante los estados de excepción y establecerá los controles judiciales y las garantías para proteger los derechos, de conformidad con los tratados internacionales. Las medidas que se adopten deberán ser proporcionales a la gravedad de los hechos. 3. No se interrumpirá el normal funcionamiento de las ramas del poder público ni de los órganos del Estado. 4. Tan pronto como hayan cesado la guerra exterior o las causas que dieron lugar al Estado de Conmoción Interior, el Gobierno declarará restablecido el orden público y levantará el Estado de Excepción. 5. El Presidente y los ministros serán responsables cuando declaren los estados de excepción sin haber ocurrido los casos de guerra exterior o de conmoción interior, y lo serán también, al igual que los demás funcionarios, por cualquier abuso que hubieren cometido en el ejercicio de las facultades a que se refieren los artículos anteriores.6. El Gobierno enviará a la Corte Constitucional al día siguiente de su expedición, los decretos legislativos que dicte en uso de las facultades a que se refieren los artículos anteriores, para que aquella decida definitivamente sobre su constitucionalidad. Si el Gobierno no cumpliere con el deber de enviarlos, la Corte Constitucional aprehenderá de oficio y en forma inmediata su conocimiento.

46 RAMELli, A., Furisprudencia penal internacional aplicable en Colombia, Ediciones Uniandes, Bogotá, D.C., 2011, p 619 
sistema de justicia transicional debe estar dirigido por la norma constitucional, la cual integra en su cuerpo los principios de derecho internacional.

Pero es importante en este punto hacer unas breves aclaraciones sobre el concepto de bloque de constitucionalidad. Los tratados ratificados por Colombia, en especial aquellos relacionados con la protección de derechos humanos, hacen parte de la Constitución Política, por lo tanto, tienen un lugar prevalente en el ordenamiento jurídico interno. En consecuencia, el bloque de constitucionalidad permite incorporar derechos y principios incluso cuando estos no han sido reconocidos expresamente en la Carta Política, pero para ello se requiere que sean derechos no limitables en estados de excepción ${ }^{47}$.

En concordancia, las normas que en nuestra constitución establecen derechos fundamentales se deben interpretar no solo de acuerdo con los tratados internacionales ratificados por Colombia sino teniendo en cuenta el denominado bloque de constitucionalidad ${ }^{48}$, razón por la cual la Corte Constitucional ha considerado que se debe hacer una interpretación conjunta de la disposición interna con la internacional e integrar dicha interpretación al ejercicio hermenéutico ${ }^{49}$.

No obstante lo anterior, la Corte Constitucional colombiana en su jurisprudencia consolidada ha establecido unas condiciones claras que deben cumplir las disposiciones convencionales del derecho internacional para incluirse en el ordenamiento jurídico interno, como son las siguientes: (1) deben reconocer un derecho fundamental; (2) el derecho reconocido no debe ser susceptible de suspenderse en estado de excepción; y (3) deben tener fundamento expreso en la Constitución. Por otra parte, la Corte Constitucional ha señalado que las disposiciones de derecho internacional humanitario hacen parte de nuestro ordenamiento de forma automática a través del bloque de constitucionalidad $^{50}$.

En consideración a lo expuesto, la Corte Constitucional colombiana en reiteradas oportunidades ha reconocido la obligatoriedad de los preceptos jurídicos internacionales que hacen parte de este bloque y ha utilizado la doctri-

47 UPRIMNY, R., Corte constitucional colombiana. T-1319 de 2001, http://www.corteconstitucional.gov.co/relatoria/2001/t-1319-01.htm, 2001 [15-10-2016].

48 GaLVIS, A, Corte constitucional colombiana. C-148 de 2005, http://www.corteconstitucional. gov.co/relatoria/2005/C-148-05.htm, 2005 [15-10-2016].

49 Ibidem.

50 Ramelli, A., «Sistema de Fuentes del Derecho Internacional Público», en Cuestiones Constitucionales Revista Mexicana de Derecho Constitucional, vol. 11 (julio-diciembre 2004), p. 160. 
na elaborada por la comisión interamericana de derechos humanos (CIDH) y los pronunciamientos de la Corte interamericana de derechos humanos (CteIDH) como criterios interpretativos a la hora de tomar decisiones. Para el desarrollo de un modelo de justicia transicional se debe interpretar según los mismos criterios, es decir, en el momento antes de construir un sistema de justicia se debe hacer un juicio sobre la normatividad internacional existente y ahí se configuran los límites ex ante del sistema. En el caso de Colombia esta normatividad en virtud del bloque de constitucionalidad, puede hacer parte de la Carta Política.

Pero el diseño del modelo de justicia transicional bajo la interpretación de los criterios de derecho internacional en muchos casos no es en sí mismo criterio suficiente para establecer un límite real a la discrecionalidad normativa de los estados en la construcción de una salida política a un conflicto armado, y aquí es donde se deben configurar unos límites ex post que definan la posible intervención de los sistemas internacionales de protección de los derechos humanos y en algunos casos del sistema penal internacional.

El desarrollo de un modelo de justicia transicional desconociendo el derecho internacional, es decir sin estar limitado ex ante o preventivamente, durante el perfeccionamiento del sistema podrá tener como consecuencia la responsabilidad del Estado por la vulneración de los derechos humanos por incumplir las normas del derecho internacional tanto las del derecho internacional de los derechos humanos, como las normas del derecho internacional humanitario por las acciones derivadas del conflicto armado; en cuanto al DDHH está «responsabilidad por violación de las normas del derecho internacional de los derechos humanos, en general, el individuo afectado podrá después de agotar los recursos internos, reclamar ante una instancia internacional o regional la terminación de la violación y la satisfacción debida frente a sus derechos conculcados. Los órganos de control internacional para la observancia por parte de los estados de los derechos humanos intentarán volver al status quo ante y eventualmente exigirán una reparación $»^{51}$.

Encontramos dos tendencias que deben concurrir: la preventiva o un juicio ex ante, frente a las normas consuetudinarias, convenciones y en algunos casos constitucionales, y ex post o restauradora y eventualmente reparadora,

51 VinUeSA, R, CIRC, Derechos Humanos y Derecho Internacional Humanitario, diferencias y complementariedad, https://www.icrc.org/spa/resources/documents/misc/5tdlj8.htm, 1998 [13-09-2016]. 
donde claramente se configura la responsabilidad del Estado por la violación de los derechos humanos ${ }^{52}$ o la responsabilidad penal individual; este debe en un principio ser el marco de los límites a un sistema propio de justicia transicional que trate de imponer un Estado. «Es difícil concebir que un sistema de justicia que se preocupa por los derechos de las víctimas pueda, al mismo tiempo, permanecer indiferente e inerte hacia las graves violaciones cometidas por los perpetradores $\gg^{53}$.

Tanto la Corte Interamericana de Derechos Humanos, nuestro sistema regional de protección, como la Corte Penal Internacional son jurisdicciones subsidiarias o complementarias, lo que implica que entran en funcionamiento en la medida que se cumplan determinadas condiciones, entre las cuales están que el Estado parte no cumpla con sus obligaciones convencionales: en el caso de la Corte Interamericana, la Convención Americana sobre Derechos Humanos (pacto de San José) ${ }^{54}$, y para la Corte Penal Internacional el estatuto de Roma $^{55}$; y que la jurisdicción interna se encuentre agotada sin que esta haya sido suficiente para resolver la situación o que habiendo resuelto determinada situación el fallo no esté acorde con el derecho internacional ${ }^{56}$.

52 Ibidem.

53 VAN Boven, T., «Study concerning the right to restitution, compensation and rehabilitation for victims of gross violations of human rights and fundamental freedoms», Comité de Derechos Humanos de las Naciones Unidas, documento de la ONU, 1993, p. 348.

54 Convención Americana sobre Derechos Humanos, https://www.oas.org/dil/esp/tratados_B-32_ Convencion_Americana_sobre_Derechos_Humanos.htm [13-09-2016].

55 Estatuto de Roma de la Corte Penal Internacional, http://www.un.org/spanish/law/icc/statute/ spanish/rome_statute(s).pdf [13-09-2016].

56 Para el Sistema Interamericano artículo 46 de la Convención Americana sobre Derechos Humanos «1. Para que una petición o comunicación presentada conforme a los artículos 44 o 45 sea admitida por la Comisión, se requerirá: a) que se hayan interpuesto y agotado los recursos de jurisdicción interna, conforme a los principios del Derecho Internacional generalmente reconocidos; b) que sea presentada dentro del plazo de seis meses, a partir de la fecha en que el presunto lesionado en sus derechos haya sido notificado de la decisión definitiva; c) que la materia de la petición o comunicación no esté pendiente de otro procedimiento de arreglo internacional, y d) que en el caso del artículo 44 la petición contenga el nombre, la nacionalidad, la profesión, el domicilio y la firma de la persona o personas o del representante legal de la entidad que somete la petición. 2. Las disposiciones de los incisos 1.a. y 1.b. del presente artículo no se aplicarán cuando: a) no exista en la legislación interna del Estado de que se trata el debido proceso legal para la protección del derecho o derechos que se alega han sido violados; b) no se haya permitido al presunto lesionado en sus derechos el acceso a los recursos de la jurisdicción interna, o haya sido impedido de agotarlos, y c) haya retardo injustificado en la decisión sobre los mencionados recursos. Y para la Corte Penal Internacional artículo 17 del Estatuto de Roma de la Corte Penal Internacional «Cuestiones de admisibilidad la Corte teniendo en cuenta el décimo párrafo del preámbulo y el artículo 1, resolverá la inadmisibilidad de un asunto cuando: El asunto sea objeto 
Dada la naturaleza de los diferentes mecanismos de justicia transicional, el Estado puede diseñar un sinnúmero de medidas, las que en algunos casos logren poner en duda el cumplimento de las obligaciones internacionales adquiridas, permitiendo que los sistemas de protección de derechos humanos, ya sean regionales como el interamericano, sancionen al Estado por la omisión en sus obligaciones y la infracción a los derechos humanos. Esta posibilidad radica en el hecho de que la eficacia real del derecho internacional, en este caso específico los sistemas de protección de derechos humanos y de la Corte Penal Internacional, depende de la fidelidad con que los derechos internos se conformen a las normas internacionales y les den efecto ${ }^{57}$.

En el caso del sistema interamericano se ha fijado un límite en relación con los mecanismos de justicia transicional: «vale la pena destacar que la Corte Interamericana eleva a estándar internacional la proscripción del uso de leyes de amnistías e indultos» ${ }^{58}$. Esta proscripción se plasma en el caso Barrios

de una investigación o enjuiciamiento en el Estado que tiene jurisdicción sobre él salvo que éste no esté dispuesto a llevar a cabo la investigación o el enjuiciamiento o no pueda realmente hacerlo; El asunto haya sido objeto de investigación por el Estado que tenga jurisdicción sobre él y éste haya decidido no incoar acción penal contra la persona de que se trate, salvo que la decisión haya obedecido a que no esté dispuesto a llevar a cabo el enjuiciamiento o no pueda realmente hacerlo; La persona de que se trate haya sido ya enjuiciada por la conducta a que se refiere la denuncia, y la Corte no pueda incoar el juicio con arreglo a lo dispuesto en el párrafo 3 del artículo 20; $\mathrm{El}$ asunto no sea de gravedad suficiente para justificar la adopción de otras medidas por la Corte. A fin de determinar si hay o no disposición a actuar en un asunto determinado, la Corte examinará, teniendo en cuenta los principios de un proceso con las debidas garantías reconocidos por el derecho internacional, si se da una o varias de las siguientes circunstancias, según el caso:

Que el juicio ya haya estado o esté en marcha o que la decisión nacional haya sido adoptada con el propósito de sustraer a la persona de que se trate de su responsabilidad penal por crímenes de la competencia de la Corte, según lo dispuesto en el artículo 5; Que haya habido una demora injustificada en el juicio que, dadas las circunstancias, sea incompatible con la intención de hacer comparecer a la persona de que se trate ante la justicia; Que el proceso no haya sido o no esté siendo sustanciado de manera independiente o imparcial y haya sido o esté siendo sustanciado de forma en que, dadas las circunstancias, sea incompatible con la intención de hacer comparecer a la persona de que se trate ante la justicia. A fin de determinar la incapacidad para investigar o enjuiciar en un asunto determinado, la Corte examinará si el Estado, debido al colapso total o sustancial de su administración nacional de justicia o al hecho de que carece de ella, no puede hacer comparecer al acusado, no dispone de las pruebas y los testimonios necesarios o no está por otras razones en condiciones de llevar a cabo el juicio.»

57 Pastor, A., Curso de derecho internacional público y organizaciones internacionales, $5^{\text {a }}$ ed., Tecnos, Madrid, 1994, p. 189.

58 Abuchaibe, H., «La Corte Interamericana de Derechos Humanos y la justicia transicional en Colombia», Revista Zero, n 26, pp 24-29. 
Altos $^{59}$ y es reiterada en el caso de los hermanos Gómez Paquiyauri contra Perú ${ }^{60}$, entre otros; peros estos casos, aunque reiterados, parten del estudio de las condiciones particulares de las leyes promulgadas, los actores y los conflictos, y como consecuencia de ese estudio la Corte IDH manifiesta la incompatibilidad de las leyes de amnistía con la convención cuando, como hasta el momento, han sido usadas para vulnerar los derechos de las víctimas y como instrumentos de impunidad de delitos graves.

La promulgación de leyes de amnistías y otros beneficios penales que afectan la acción o la responsabilidad penal no pueden ir en contravía de las obligaciones del Estado de investigar, juzgar y sancionar los delitos graves. «Los Estados deberán investigar los crímenes de guerra posiblemente cometidos por sus ciudadanos o sus fuerzas armadas, así como en su territorio, y encausar, si procede, a los imputados. Deberán así mismo investigar otros crímenes de guerra que sean de su competencia y encausar, si procede, a los imputados» ${ }^{61}$. Las amnistías, los indultos y otros beneficios son jurídicamente posibles. «Las autoridades no están obligadas en absoluto a conceder una amnistía al final de las hostilidades, sino que se les pide que lo consideren detenidamente y se esfuercen por concederlas ${ }^{62}$.

El derecho internacional en las últimas décadas sufrió una transformación del juzgamiento de la responsabilidad de los estados por la vulneración de los derechos humanos a la responsabilidad individual en específico de quienes cometieron esas violaciones. Esto no implica que en el derecho internacional no se hayan juzgado individualmente a personas por graves crímenes contra la humanidad: históricamente desde el tribunal de Núremberg y Tokio, y en la década de 1990 con la conformación de tribunales con el fin de responder a las atrocidades cometidas durante el conflicto en ex Yugoslavia (Tribunal Penal Internacional para ex Yugoslavia) y los asesinatos en masa en Ruanda (el Tribunal Penal Internacional para Ruanda); también se han constituido tribunales mixtos, es decir, para juzgar delitos nacionales e internacionales, como

59 Corte Interamericana de Derechos Humanos (CteIDH), 14 Mar. 2001 Caso Barrios Altos contra Perú, http://www.corteidh.or.cr/doc s/casos/articulos/Seriec_75_esp.pdf, 2001 (consultado el 30/ octubre/2016.

60 Corte Interamericana de Derechos Humanos (CteIDH), 8 Jul. 2004 Caso hermanos Gómez Paquiyauri contra Perú, http://www.corteidh.or.cr/docs/casos/articulos/seriec_110_esp.pdf, 2004 [30-10-2016]

61 HenCKaERTS, J. y Doswld-BeCK L., El derecho internacional humanitario consuetudinario, Volumen I: Normas, Norma 158, CICR, Ginebra, Suiza, 2005, p. 687.

62 Ibid., p. 694. 
los conformados en Kosovo, Bosnia-Herzegovina, Timor Leste, Sierra Leona, Camboya y en el Líbano. Estos tribunales ad hoc se han creado posteriormente a que sucedieran graves violaciones de derechos humanos, ${ }^{63} \mathrm{y}$ siempre han concitado serias críticas frente a sus competencias, al principio de legalidad, el de juez natural, dada su creación posterior ${ }^{64}$.

El establecimiento de una Corte Penal Internacional soluciona los problemas de los tribunales ad hoc pero tardó más de cuarenta años en cristalizarse, a partir de la creación de las Naciones Unidas. La Asamblea General creó el 21 de noviembre de 1947 la Comisión de Derecho Internacional, con el fin de promover el desarrollo del Derecho Internacional y su codificación.

Después de una ardua labor de muchos años se logró elaborar un estatuto para la Corte Penal Internacional, el cual entró en vigor internacional el $1^{\circ} \mathrm{de}$ julio de 2002, después de ser aprobado el 17 de julio de 1998, en Roma. Dicho estatuto comienza con la exposición de un Preámbulo que repite la determinación de la Conferencia de «poner fin a la impunidad (...) y así contribuir a la prevención de nuevos crímenes» ${ }^{65}$.

El Estatuto de Roma que establece la Corte Penal Internacional fue ratificado en Colombia por «el art. $1^{\circ}$ del Acto Legislativo 2 de 2001, que facultó al Estado colombiano para reconocer la jurisdicción de la Corte Penal Internacional en los términos previstos en el Estatuto de Roma adoptado el 17 de Julio de 1998 por la Conferencia de Plenipotenciarios de las Naciones Unidas $\mathrm{y}$, consecuencialmente, ratifica este tratado de conformidad con el procedimiento establecido en la Constitución. Con base en dicha facultad, el Estado colombiano aprobó el Estatuto de Roma mediante la Ley 742 de 2002, y tanto

63 Comité Internacional de la Cruz Roja (CIRC), Tribunales AD HOC, 2010, https://www.icrc. $\mathrm{org} / \mathrm{spa} /$ war-and-law/international-criminal-jurisdiction/ad-hoc-tribunals/overview-ad-hoctribunals.htm, 2010 [28-10-2016].

64 «En mérito de los principios de legalidad y del juez natural, no son permitidos los jueces ad $h o c$, o sea crear juzgados después que la conducta presumiblemente penal se hubiere producido, lo que se compendia en el principio "Nemo iudex sine lege": "no puede haber juez ni proceso sin norma que los establezca y regule"». Pero la exigencia de un juez natural no solamente se trata de un principio procesal, sino que se reconoce como derecho de quienes se someten a la actividad jurisdiccional, y en nuestro ordenamiento constitucional se lo ha ubicado como una garantía del derecho a la defensa: «Ser juzgado por una jueza o juez independiente, imparcial y competente». YEPEZ, M., «Conflictos en la jurisdicción penal», http://www.derechoecuador. com/articulos/detalle/archive/doctrinas/derechopenal/2011/07/06/conflictos-en-la-jurisdiccion-penal, 2011 [25-10-2016].

65 Ambos, K. y Guerrero, O. (compls.), Prefacio del «Estatuto de Roma», Universidad Externado de Colombia, Bogotá, 1999. 
aquel como ésta fueron declarados exequibles en Sentencia de Constitucionalidad C-578 de 2000 M. P. Manuel José Cepeda Espinosa ${ }^{66}$.

La Corte Penal Internacional constituye un importante punto de llegada en la evolución del derecho internacional, por cuanto por primera vez se cuenta con un catálogo taxativo de conductas que constituyen graves crímenes de Derecho Internacional, que sirven de límite a los instrumentos de justicia transicional, dado que un tratamiento equivocado de la legislación interna de estos delitos o por lo menos fuera de las condiciones que establece el estatuto de roma en especial su artículo 17 implicaría necesariamente la intervención de la CPI. «Los delitos de competencia de tal Corte no pueden ser sustraídos de la acción efectiva de la justicia, y por lo tanto, su tratamiento mediante amnistías e indultos deberá realizarse mediante la aplicación de un esquema jurídico que responda en forma equilibrada a los principios de verdad, justicia y reparación, so pena de ser asumidos por dicha Corte mediante una acción complementaria a la del Estado, tras considerar que los procesos judiciales internos desconocieron el derecho a la justicia para la sociedad y las víctimas» ${ }^{67}$.

En el caso concreto del Estado colombiano el estatuto de Roma entró en vigor el 1 de Julio de 2002, siendo ratificado el 5 de agosto de ese mismo año, con una declaración que señalaba que: de acuerdo al artículo 124 del Estatuto de Roma, por un período de siete años, Colombia no aceptaba la jurisdicción de la Corte solo y únicamente por crímenes de guerra cometidos en territorio colombiano o por colombianos nacionales. Lo anterior hizo pensar que los actos de los grupos armados al margen de ley estaban fuera de la jurisdicción de Corte Penal Internacional, pero «La salvedad solamente opera para crímenes de guerra. No hay salvedad para crímenes de lesa humanidad» ${ }^{68}$.

La jurisdicción de la Corte Penal Internacional, como ya lo mencionamos, es de carácter subsidiario o complementaria y solo puede actuar sobre crímenes cometidos después de su entrada en vigor, es decir después del 1 de julio de 2002, en el caso colombiano. La posibilidad latente de intervención de la Corte Penal Internacional fija un límite al diseño de los mecanismos de

66 ARAujo, J., «Corte constitucional colombiana. C-928 del 2006», http://www.corteconstitucional.gov.co/relatoria/2001/t-1319-01.htm 2006 [15-10-2016]

67 Vega, J. y Martinez, M., «Delitos contra el Régimen Constitucional y Legal, http://humanitatis.blogspot.com.co/2008/03/delitos-contra-el-regimen.html, 2008 [16-10-2016]

68 Diario El Tiempo, «Corte Penal Internacional sigue pista a la parapolítica, asegura su fiscal jefe, Luis Moreno Ocampo», http://www.eltiempo.com/archivo/documento/CMS-3775574, 2007 [30-09-2016]. 
justicia transicional; en tal sentido, la jurisdicción penal internacional debe reconocer los beneficios que el Estado otorgue en el marco de la justicia transicional, es decir, deberá reconocer como válidos los indultos, amnistías y otros beneficios otorgados por los estados soberanos ${ }^{69}$, siempre y cuando la decisión no obedezca al propósito de sustraer al acusado de su responsabilidad penal por crímenes de competencia de la Corte o no hubiese sido instruido en forma independiente o imparcial de conformidad con las debidas garantías procesales reconocidas por el derecho internacional o lo hubiere sido de alguna manera que, en las circunstancias del caso, fuere incompatible con la intención de someter a la persona a la acción de la justicia ${ }^{70}$.

La implementación de mecanismos de justicia transicional puede ser de carácter judicial o extra judicial; la jurisdicción penal internacional ha manifestado que cuando los beneficios provienen de medidas extrajudiciales tomadas por el ejecutivo como decisiones políticas la Corte Penal Internacional podrá intervenir, puesto que las decisiones administrativas no hacen tránsito a cosa juzgada. Por lo cual «En el caso de la garantía de cosa juzgada, a mi manera de ver, sería imposible aplicarla a aquellos casos como la amnistía, donde -por definición- no existe una cosa juzgada, sino la decisión política de no llevar a cabo una investigación $\gg^{71}$. Este límite a los modelos de justicia transicional evoca una situación más peligrosa que una amnistía otorgada en contraposición del derecho internacional, y es que un gobierno, para evitar la intervención de la Corte Penal Internacional, estructure procesos judiciales, blandos y despreocupados de los derechos de las víctimas, pero ceñidos a la normatividad interna. «Otra cosa, y potencialmente muy desgraciada, sería la posibilidad de los perdones luego de la ejecución de un proceso acorde a la ley. En efecto, si un Estado hipotéticamente llevase a cabo un juicio mínimamente correcto desde el punto de vista del debido proceso pronunciase una sentencia, un perdón y liberase al criminal» ${ }^{72}$. Aun así, y aunque formalmente se pudiese interponer la excepción de cosa juzgada, la Corte Penal Internacional tendría el deber de intervenir con el fin de que se respetaran los derechos de

69 Abelló, J., «El Delito Político y la Corte Penal Internacional», Revista de Derecho, Universidad del Norte, 21 (junio 2004), p. 202.

70 Estatuto de Roma Corte Penal internacional art. 20, $\mathrm{n}^{\circ} 3$ lit. a) y b).

71 GONZÁLEZ, E., «El principio de la complementariedad en el Estatuto de Roma y algunas de sus consecuencias en el ámbito interno», www.iccnow.org/español/; ABELló, J., «El Delito Político y la Corte Penal Internacional», Revista de Derecho, Universidad del Norte, 21 (junio 2004), p. 231.

72 Ibidem. 
las víctimas y del conglomerado social y que no se sustraiga al delincuente de su responsabilidad penal.

El derecho internacional explicita la necesidad de limitar y asegurar que en los acuerdos de paz no se incluyan amnistías, indultos o beneficios que impliquen el desconocimiento de los derechos de la víctimas y de la responsabilidad del autor en casos de genocidio, crímenes de guerra o crímenes de lesa humanidad, delitos internacionales relacionados con la raza, el género y el sexo, y que se garantice que ningún beneficio concedido con anterioridad constituya un obstáculo para el enjuiciamiento ante cualquier tribunal creado o asistido por las Naciones Unidas, o por la Corte Penal Internacional ${ }^{73}$.

El cumplimiento de los juicios ex ante y ex post a los acuerdos de paz evitarían la injerencia de los órganos internacionales como el Sistema Interamericano de Protección de los Derechos Humanos y la Corte Penal Internacional que pudieran generar inseguridad jurídica sobre el desarrollo de los acuerdos.

\section{CONCLUSIONES}

1. Los límites ex ante o preventivos y los ex post restauradores o reparadores crean una tensión con la discrecionalidad del Estado al momento de diseñar, desarrollar y poner en marcha un modelo o sistema de justicia transicional. Esta tensión entre los resultados esperados y los medios seleccionados debe generar flexibilidad de los mecanismos de justicia transicional que se implementen, los cuales deben estar acordes con el respeto del derecho internacional.

2. Los derechos humanos son un imperativo del derecho internacional y normas de ius cogens que deben ocupar un sitio preponderante y significativo en las negociaciones para superar una situación de violencia generalizada y en la posterior implantación de un modelo de justicia transicional.

3. Los esquemas de justicia transicional deben ser únicos y responder a las necesidades de cada Estado; no es una buena práctica intentar establecer modelos de justicia transicional universalmente aplicables.

73 Chinchón, J., «Modelos de persecución penal y Justicia Transicional en Iberoamérica. Algunas enseñanzas jurídico internacionales tras los procesos de transición iberoamericanos: Impunidad fáctica, amnistías e indultos», en Capellà, R.M. y Ginard, I.F. (coords.), Represión política, justicia y reparación. La memoria histórica en perspectiva jurídica (1936-2008), Ediciones Documenta Balear, Palma de Mallorca, 2009, pp. 255-339. 
4. Los límites que establecen el Derecho Internacional de los Derechos Humanos y el Derecho Internacional Humanitario hacen posible establecer algunos principios generales como (1) el esclarecimiento de la verdad; (2) la aplicación de justicia; (3) la reparación a las víctimas; (4) las garantías de no repetición.

5. Las amnistías y los indultos son contrarios al Derecho Internacional siempre que sean herramientas dirigidas a promocionar la impunidad y a vulnerar los principios generales antes mencionados.

6. Los conflictos armados crean situaciones aberrantes que de formas inimaginables quebrantan la dignidad humana, no solo a nivel del derecho que se le reconoce al individuo sino también al conglomerado, pueblo o nación; por tanto, es recomendable siempre una salida política de la situación, y dicha salida exige de los gobernantes no solo la aplicación de las normas internacionales y en algunos casos de las nacionales, también exige soluciones creativas que permitan lograr el objetivo ulterior de la paz.

Como lo manifestamos al principio de estas líneas el lector tiene ahora algunas herramientas para determinar si el modelo colombiano de justicia transicional se encuentra dentro de los límites del derecho internacional, no solo desde un juicio ex ante o preventivo sino también desde un juicio ex post o restaurativo y eventualmente reparador; más aún, si bien usamos el modelo de Colombia como ejemplo, el discurso aplicado a los límites del derecho internacional es posible aplicarlo sobre cualquier otro modelo de justicia transicional.

\section{BibLIOGRAFÍA}

\section{Libros, articulos y publicaciones}

Platón, La República (Traducción José Tomas y García), Panamericana, Bogotá, 1997, p. 267.

Comité Internacional de la Cruz Roja (CIRC), Servicio de Asesoramiento en Derecho Internacional Humanitario $\ll_{i} Q$ ué es el derecho internacional humanitario?», https://www.icrc.org/spa/assets/files/other/dih.es.pdf, 2004 [10-092016].

ONU Mujeres, «Derecho Internacional de los Derechos Humanos», http://www. endvawnow.org/es/articles/1485-derecho-internacional-de-los-derechos-humanos.html, 2009 [12-09-2016].

Comité Internacional de la Cruz Roja (CIRC), Servicio de Asesoramiento en Derecho Internacional Humanitario, «Principios Generales del Derecho Penal Internacional», https://www.icrc.org/spa/assets/files/2014/general-principlesof-criminal-icrc-spa.pdf, 2014 [10-10-2016]. 
IBARRA, A., «Justicia transicional: la relación Derecho-Poder en los momentos de transición», Revista de Derecho, 45 (enero-junio de 2016), http://rcientificas. uninorte.edu.co/index.php/derecho/article/viewArticle/7176/8248\#num7, 2016 [28-10-2016].

VALENCIA, H., «Introducción a la justicia transicional», conferencia magistral impartida en la Cátedra Latinoamericana «Julio Cortázar» de la Universidad de Guadalajara, 2007, p. 1.

The International Center for Transitional Justice, «¿Qué es la Justicia Transicional?», https://www.ictj.org/es/que-es-la-justicia-transicional [13-10-2016].

Gobierno de la República de Colombia y FARC-EP, «Acuerdo Final para la Terminación del Conflicto y la Construcción de una Paz Estable y Duradera», http:// www.acuerdodepaz.gov.co/el-acuerdo-de-paz, 2016

Gobierno de la República de Colombia y FARC-EP, «Comunicado Conjunto \#53 Informe Conjunto de la Mesa de Conversaciones», http://centromemoria.gov.co/ wp-content/uploads/2015/06/Acuerdo-para-establecer-la-comisi\% C3\% B3nde-esclarecimiento-de-la-verdad.pdf, 2016.

DE GREIFF, P., Report of the Special Rapporteur on the promotion of truth, justice, reparation and guarantees of non-recurrence, United Nations, 2012, p. 6.

GonZÁLEZ-SAlzBERG, D., «El Derecho a la Verdad en Situaciones de Post-Conflicto Bélico de Carácter No-Internacional», Revista Colombiana de derecho internacional ildi, $\mathrm{n}^{\mathrm{o}} 12$, edición especial (2008), pp. 435-468.

Organización Naciones Unidas (ONU), Fusticia Transicional y Derechos Económicos, Sociales y Culturales, Naciones Unidas, 2014, pp. 62 y ss.

The International Center for Transitional Justice, «¿Qué es la Justicia Transicional?», https://www.ictj.org/es/que-es-la-justicia-transicional [13-10-2016].

GómEZ-SuÁREZ, A, «Confíen en crear su propio modelo», http://www.elespectador.com/noticias/nacional/confien-crear-su-propio-modelo-articulo-5 50716, 2015 [12-09-2016].

Comité Internacional de la Cruz Roja (CIRC), International Review of de Red Cross, vol. 87, no 857 (marzo de 2005), https://www.icrc.org/spa/assets/files/other/ icrc_003_0860.pdf [28-10-2016].

PigraU, A, La jurisdicción universal y su aplicación en España, RxDH, Barcelona, 2009, pp. 130-131. También en apoyo de las tesis favorables a la persecución: CAPELLÀ ROIG, M., «Los crímenes contra la humanidad en el caso Scilingo», REEI, $\mathrm{n}^{\mathrm{o}} 10(2005)$.

Grossman, C., «Reflexiones sobre el Sistema Interamericano de Protección y Promoción de los Derechos Humanos», en La Corte y el Sistema Interamericano de Derechos Humanos, San José, 1997, p. 246.

RAMELLI, A., Furisprudencia penal internacional aplicable en Colombia, Ediciones Uniandes, Bogotá, D.C., 2011, p. 619.

- «Sistema de Fuentes del Derecho Internacional Público», en Cuestiones Constitucionales Revista Mexicana de Derecho Constitucional, vol. 11 (julio-diciembre 2004), p. 160. 
VINUESA, R., CIRC, «Derechos Humanos y Derecho Internacional Humanitario, diferencias y complementariedad», https://www.icrc.org/spa/resources/documents/misc/5tdlj8.htm, 1998 [13-09-2016].

VAN BOVEN, T., «Study concerning the right to restitution, compensation and rehabilitation for victims of gross violations of human rights and fundamental freedoms», Comité de Derechos Humanos de las Naciones Unidas, documento de la ONU, 1993, p. 348.

PASTOR, A., Curso de derecho internacional público y organizaciones internacionales, $5^{\mathrm{a}} \mathrm{ed}$., Tecnos, Madrid, 1994, p. 189.

ABuchaibe, H., «La Corte Interamericana de Derechos Humanos y la justicia transicional en Colombia», Revista Zero, n 26, pp 24-29.

HeNCKAERTS, J. y DOSWLD-BECK L., El derecho internacional humanitario consuetudinario, Volumen I: Normas, Norma 158, CICR, Ginebra, Suiza, 2005, p. 687.

Comité Internacional de la Cruz Roja (CIRC), Tribunales AD HOC, 2010, https:// www.icrc.org/spa/war-and-law/international-criminal-jurisdiction/ad-hoctribunals/overview-ad-hoc-tribunals.htm, 2010 [28-10-2016].

YEPEZ, M., «Conflictos en la jurisdicción penal», http://www.derechoecuador.com/ articulos/detalle/archive/doctrinas/derechopenal/2011/07/06/conflictos-enla-jurisdiccion-penal, 2011 [25-10-2016].

Ambos, K. y Guerrero, O. (comps.), Prefacio del «Estatuto de Roma», Universidad Externado de Colombia, Bogotá, 1999.

Vega, J. y Martinez, M., «Delitos contra el Régimen Constitucional y Legal, http://humanitatis.blogspot.com.co/2008/03/delitos-contra-el-regimen.html, 2008 [16-10-2016].

Diario El Tiempo, «Corte Penal Internacional sigue pista a la parapolítica, asegura su fiscal jefe, Luis Moreno Ocampo», http://www.eltiempo.com/archivo/documento/CMS-3775574, 2007 [30-09-2016].

ABelló, J, «El Delito Político y la Corte Penal Internacional» Revista de Derecho, Universidad del Norte, 21 (junio 2004), pp. 202.

CAPELLÀ, R.M. y GINARD, I.F. (coords.), Represión política, justicia y reparación. La memoria histórica en perspectiva jurídica (1936-2008), Ediciones Documenta Balear, Palma de Mallorca, 2009, pp. 255-339.

\section{Normas y sentencias}

Corte constitucional colombiana.

—C-293 de 1995. C. Gaviria.

-C-163 de 2000. F. Morón.

-C-1149 de $2001 \mathrm{~J}$. Araujo.

-T-1267 de 2001. R. Uprimny.

-C-228 de 2002. M. Cepeda y E. Montealegre.

-C-014 de 2004. J. Córdoba. 
-C-454 de 2006. J. Córdoba

-C-048 de 2001. F. Morón.

-C-225 de 1995. A, Martínez.

-C-578 de 1995. E. Cifuentes.

-C-358 de 1997. E. Cifuentes.

-C-191 de 1998. E. Cifuentes.

-T-1319 de 2001. R. Uprimny.

-C-148 de 2005. A. Galvis.

-C-928 del 2006. J. Araujo.

Corte Interamericana de derechos humanos.

- Caso Barrios Altos contra Perú, 14 Mar. 2001

—Caso hermanos Gómez Paquiyauri contra Perú, 8 Jul. 2004

Congreso de Colombia.

—Ley 418 de 1998. Ley de Orden Público.

- Ley 600 de 2000. Código de procedimiento penal.

—Ley 975 de 2005. Ley de Justicia y Paz.

\section{Tratados Internacionales}

Convención Americana sobre Derechos Humanos, https:/www.oas.org/dil/esp/ tratados_B-32_Convencion_Americana_sobre_Derechos_Humanos.htm [1309-2016].

Estatuto de Roma de la Corte Penal Internacional, http://www.un.org/spanish/law/ icc/statute/spanish/rome_statute(s).pdf [13-09-2016]. 
0000 